\title{
Plague, pox and the physician in Aberdeen, |495-15|6
}

\author{
K Jillings \\ Lecturer in History, School of History, Philosophy and Classics, Massey University, Palmerston North, New Zealand
}

\begin{abstract}
This article discusses responses to disease in Aberdeen during a formative period in the provision of healthcare within the city. The foundation of King's College was followed, in 1497, by the establishment of the first royally endowed university Chair of Medicine in the British Isles, and its first incumbent, James Cumming, was employed by the local government as the first city doctor in 1503. His appointment had been preceded in I 497 by another legislative innovation in Aberdeen, when its council became the first civic body in the British Isles to implement regulations against the threat of the Great Pox (usually considered to be syphilis). It had subsequently to pass measures to prevent the spread of plague to the city, and these were typical of those already imposed elsewhere in Scotland and on the continent. Their apparent success in staving off plague lasted until $15 \mid 4$, when the city was struck by a severe outbreak which lasted two years.
\end{abstract}

\author{
Correspondence to $K$ Jillings, \\ School of History, Philosophy and \\ Classics, Massey University, Private \\ Bag II 222, Palmerston North, \\ New Zealand \\ tel. +6463504297 \\ e-mail K.A.jillings@massey.ac.nz
}

KEYWORDS Aberdeen, legislation, outbreak, physician, plague, syphilis

DECLARATION OF INTERESTS No conflict of interests declared.

\section{INTRODUCTION}

This article will discuss responses to plague and the Great Pox (usually considered to be syphilis) in early modern Aberdeen, with a particular focus on the contribution made by medical and government authorities in preventing outbreaks between 1495 and 1516 according to prevailing beliefs about disease causation and transmission. This was a very significant period in Aberdeen's medical history for three reasons:

I. In 1497 its local government authorities became the first in the British Isles to take preventative action against the spread of the Great Pox;

2. In 1503 the city gained its first permanent physician; he also held the first Chair of Medicine at nearby King's College, the first such royally endowed position at any British university;

3. In 1514-16 the city suffered its first known epidemic of plague, which prompted the council to implement a series of measures to eliminate the presence of the disease and its spread by both contagion and miasma.

Each of these significant aspects of Aberdeen's medical history will be discussed, as will earlier responses to the threat of plague from elsewhere, in order to shed light on an important period of healthcare and disease in one of Scotland's largest burghs.

\section{I497: THE GREAT POX IN ABERDEEN}

Even before plague itself broke out within Aberdeen, the local government had to confront the threat from an entirely different and hitherto unknown disease, which commentators across Europe acknowledged to have first broken out in Italy during the months after February I 495 among soldiers fighting for Charles VIII of France in his bid for the kingdom of Naples. Scholars described it variously as the 'Great Pox' (in contrast to smallpox), the 'disease of Naples', the 'French disease' and 'Morbus Gallicus'. Modern scholarly debate continues about the origins and clinical identification of this malady, particularly over whether it was a form of syphilis that already existed in Europe before the return of explorers from the New World, perhaps evolving as a result of favourable biological and ecological changes. Whatever its exact origins, contemporaries quickly acknowledged the venereal character, high contagiousness and low mortality of this new disease. ${ }^{1,2 ; *}$

Mercenaries drawn from all over Europe who had fought in Charles VIII's short-lived Italian campaign subsequently returned home, spreading the disease as they went. The extreme virulence of the Great Pox led to medical and municipal efforts to tackle the threat it posed, with magistrates in Aberdeen becoming the first civic authority in the British Isles to enact such legislation. On 2I April 1497 they decreed that 'for the avoidance of the infirmity come out of France and strange parts... all light women [are to] be charged and ordained to decist [sic] from their vices and sin of venery'. ${ }^{3}$ They were ordered to shut up shop and seek lawful employment, or face branding and banishment. ${ }^{3}$

While early continental commentators believed that the disease could also be spread through the air or via food and drink, descriptions of its clinical manifestations clearly showed it was the venereal form that prevailed. Italian commentators, including Giovanni daVigo and the military surgeon Marcello Cumano, noted the appearance of a 
skin ulceration on the genitals coloured blue, black or white, followed by sores and pustules breaking out all over the entire body. Secondary manifestations included painless regional lymphadenopathy, fever, mouth ulcers and a maculopapular rash, which could give way to the erosion of tissue in the extremities, painful tumours and eventual death. ${ }^{124}$ The appearance of genital ulcers in the primary phase distinguished the Great Pox from the more familiar symptoms of plague and were most likely identifiable to the Aberdeen authorities despite the absence of a resident physician. Sexual promiscuity was therefore held particularly culpable for its spread, resulting in the city's prostitutes being targeted. While the Aberdeen council offered them the choice of rehabilitation, their automatic expulsion was one response favoured by magistrates elsewhere, including Paris. ${ }^{4.5}$

Whether due to the authorities' swift actions or a more obscure factor, the actual spread of the Great Pox to the city at the turn of the sixteenth century remains unsubstantiated, although it might simply have gone unrecorded. Burghs further south definitely did not fare so well. The disease spread rapidly throughout Europe and was present in Edinburgh by September 1497, when the authorities banished sufferers of 'this contagious sickness called the Grandgor' to the island of Inchkeith in the Firth of Forth, ordering them to remain there 'until God provides for their health'. ${ }^{6,7+7}$ By February 1498 it had spread to Dalry, Glasgow, Stirling and Linlithgow. ${ }^{4}$ Treatment included the application of various ointments to the lesions, and the ledger of Andrew Halyburton, Scots conservator in the Low Countries, shows that mercury and guaiacum, remedies commonly in use on the continent, were imported into Scotland before $1503 .{ }^{4}$

The particular speed of the Aberdeen authorities' reaction and their recognition of the perceived origins of the Great Pox are truly remarkable. There are a number of possible routes by which information about the new disease (and, of course, the disease itself) reached Scotland and, particularly, Aberdeen. It is possible that Scots were among its first European victims, as the mercenaries fighting for Charles VIII in the Italian Wars included at least 500 Scotsmen. One hundred Scots archers were recorded as participating in the battle of Fornovo near Parma on 6 July 1495, and it was the examination of infected soldiers from this battle that enabled Marcello Cumano to record his detailed description of the symptoms of the disease (noted above). Many participants would have returned home to Scotland, probably bringing with them the disease and reports of its existence. ${ }^{1,8}$

Not only did Scottish mercenaries participate in continental campaigns such as Charles VIll's attempted conquest of the kingdom of Naples, but foreign soldiers also joined forces that were involved in the ongoing Anglo-Scottish hostilities and their participation could plausibly have been a factor in spreading the Great Pox to Scotland. Perkin Warbeck, a pretender to the English throne under the guise of the duke of York, was first received at the court of Charles VIII of France and, having arrived at the Scottish King James IV's court in November 1495, subsequently launched a joint invasion of England from Scotland with the king's forces in September 1496. Warbeck's followers were reported to number I,400 men 'of all manner of nations', ' and it has been suggested that infected participants spread the new disease into both Scotland and England during the failed invasion and subsequent skirmishes in the months that followed. ${ }^{4}, 10$ Although the burgesses of Aberdeen had been excused by the king from participating in the raid, at least eight members of Warbeck's retinue were funded to lodge in the city for a month" and could have carried the disease with them.

In addition to military links with the continent, Aberdeen maintained important contacts through diplomacy and education during the two years between the reported appearance of the disease in Italy and the council's proclamation. In early February I 495 Pope Alexander VI, barely a week after officially confirming Charles VIII's claim to the Neapolitan kingship and less than two weeks before the French king's forces entered Naples, met with William Elphinstone, bishop of Aberdeen, and granted him a Bull of Foundation for a new college in Old Aberdeen. On his journey home Elphinstone undertook other diplomatic work in various parts of Europe, reaching Bruges at Easter 1495.' The first incumbent of the Chair of Medicine at King's College, James Cumming, studied at the medical faculty at Cologne and between 1493 and 1499 acted as Elphinstone's diplomat in the Low Countries, while Hector Boece, the first principal of the newly founded university, studied and taught at Paris before his arrival in Aberdeen some time in 1497. ${ }^{2}$

National diplomacy could also have enabled information about the Great Pox to be passed on, as royal couriers did occasionally visit the city - including in May 1496 on other matters, while a Spanish embassy spent ten days at the royal court in Stirling in April $1497^{\circ}$ and could have brought news of the disease which was subsequently conveyed to authorities in Aberdeen. Although conjectural, it is surely likely that information about the Great Pox, as well as the disease itself, was carried to Scotland - and to Aberdeen in particular - through one of these diplomatic, educational or military links with the continent.

\section{PLAGUE IN FIFTEENTH-CENTURY ABERDEEN}

While some inhabitants of Aberdeen might possibly have fallen victim to the Great Pox, the city's residents fared remarkably better in their experience of plague - better, in fact, than other towns either in Scotland or elsewhere. 
The detailed council registers were used to record all matters of concern to the local government authorities regarding the town's political, commercial, spiritual and social affairs. Although these have survived almost in their entirety from 1398, the only mention of plague during most of the fifteenth century dates from I40I, when the council prohibited strangers arriving from the apparently plague-ridden south. ${ }^{13}$ There are a number of possible reasons for Aberdeen's avoidance of plague, including the city's comparatively isolated location, the slightly colder temperatures and the reported absence of rodents, ${ }^{14}$ but none is entirely satisfactory, particularly since the epidemiology of past 'plagues' remains open to debate. . $^{15-21 ; \neq}$ In any case, it was almost a century before plague from the south troubled Aberdeen's council again, and the renewed threat of the disease in 1498 and subsequently thereafter might have played a part in its appointment of the first resident physician only a few years later.

\section{I503: ABERDEEN GAINS ITS FIRST RESIDENT PHYSICIAN}

Medieval Aberdeen had only three medical practitioners recorded as visiting or living in the city during the 100 years before the foundation in 1495 of Scotland's third university, King's College, in the neighbouring burgh of Old Aberdeen. ${ }^{22,23}$ Most residents would have looked to the barber surgeons of the town for medical relief, specifically the service of blood-letting which was considered necessary to maintain humoral equilibrium and hence good health. While specific records of the barbers' services are few and far between, their existence is substantiated by their occasional participation during the early sixteenth century in the Candlemas pageant, held annually as part of communal worship. ${ }^{23-25}$

In May I497 a major development in the provision of local healthcare took place when King James IV, who had a clear interest in medical theory and practice, donated an annual stipend to pay for a Chair in Medicine at King's College. While this did not equate to a thriving programme of medical teaching, it does at least represent the first royally endowed Chair of Medicine in the British Isles; the earliest such Chair in England was bestowed on Cambridge University by Henry VIII in I540.

The first incumbent, James Cumming, was appointed burgh physician by the town council in October 1503 . He was given a yearly salary of ten merks and various fishing rights on the condition that he and his family came to live in the town, and that he was to visit the sick 'and show them his medicine'. ${ }^{26}$ The offer of such financial incentives indicates that the authorities felt the need to secure the services of a trained physician, possibly in response to the ongoing threat to the town of both plague and the Great Pox (and the timing of James IV's endowment of the Chair of Medicine only a month after the enactment of regulations preventing the
Great Pox is a further indication that this disease was a source of concern). It is not clear exactly how many residents consulted Cumming for private medical care, but it is reasonable to assume that his medical expertise would have been very valuable in tackling both the threat and the actual presence of these diseases.

\section{CONTEMPORARY BELIEFS ABOUT DISEASE CAUSATION AND TRANSMISSION}

Responses to plague not only in Aberdeen but also in other towns in Scotland as well as across most of Europe were based on ideas about disease causation and transmission that had changed very little since they were first suggested by classical Greek medical writers such as Hippocrates and Galen. Plague, in common with most diseases, was believed to spread in two ways - miasma (polluted airborne vapours) and contagion (contact, although not necessarily directly, with infected goods, animals and people). Although theoretically these were two different concepts, in practice they were interchangeable, and adherence to either theory (or both) could bring about the same remedial course of action.

Recent scholarship has reassessed the view that empirical urban administrators and university-trained physicians differed in their 'solutions to the management of plague', with the former adhering to contagion theory as against a belief in miasmas advocated by the latter. ${ }^{27} \mathrm{~A}$ study of the local control of plague in German towns, for example, concluded that neither governors nor physicians saw a need 'to strictly distinguish between these different concepts [of miasma and contagion] relating to the spread of diseases' ${ }^{28}$ In the matter of plague control, the two authorities might be said to diverge only insofar as the physician treated the individual patient while governors were necessarily concerned with protecting the health of all those under their jurisdiction. Physicians tackled plague not only through diagnosis of (literally 'seeing through') a person's symptoms but also through consideration of their particular physiological make-up, including age, gender and internal humoral balance, as well as external factors, such as the season and the juxtaposition of the planets, which consequently dictated the remedies they suggested.

Urban governments, on the other hand, were concerned with preventing the spread of plague at a communal rather than individual level and so their actions were focused on eliminating sources of potential or actual infection within their locality. This included implementing orders for cleaning up the environment to eliminate miasmas (which were generated by filthy, malodorous conditions) and preventing people from entering or leaving the town to limit contact with possibly infected places. These were the kinds of regulations implemented by the authorities in Aberdeen in 1498, when plague threatened the city for the first time in almost a century. 


\section{PLAGUE THREATENS ABERDEEN: |498-1513}

Plague had broken out in Scotland's central belt early in 1498 and government legislation to tackle the presence of the 'contagious infirmity of pestilence' had been issued by the council in Edinburgh in March of that year. ${ }^{26}$ Two months later the Aberdeen authorities issued their own regulations, which were specifically aimed at preventing 'the pestilence, and strange sickness as before'. Perhaps due to advice received from medical or municipal authorities elsewhere, magistrates clearly understood that the disease that now threatened was different from the 'strange sickness' the town had faced 'as before' - surely a reference to the Great Pox - and therefore implemented different measures from those that had been decreed in April 1497.

Since plague had not actually broken out within the burgh, the main concern was to prevent potential sources of infection from entering it in the first place. Residents were ordered to keep their back gates shut and to strengthen any walls surrounding their property in order to stop 'all sickness and unlawful folks' entering. The four entrances of the town were to be guarded constantly and locked at night, and a licence was required to lodge visitors. ${ }^{29}$ It might be assumed that this was successful to prevent plague from entering the town as no more action was taken by the council until the summer of the following year, when once more the entrances to the town were to be closed and no-one was allowed to enter or leave without permission. ${ }^{30-32}$ Late in 1498, authorities in Edinburgh had restricted residents' movements within the town itself and had ordered schools, taverns and shops to close, an indication that sickness was actually present. ${ }^{6}$ In Aberdeen the fact that no such regulations were ordered makes it almost certain that plague had been successfully prevented.

The following year, 1500, saw a particularly virulent epidemic sweep across much of Scotland's central belt and Fife, but it is likely that Aberdeen again managed to prevent plague within the city itself. Even though in August that year the magistrates ordered 21 inhabitants to be enclosed within their houses for 15 days, this was most likely merely a precaution against possible infection being spread to healthy residents rather than an indication that plague was actually present. The residents who were forcibly quarantined had come into contact with people and goods recently arrived in a ship from Danzig (Gdansk, in modern-day Poland), where plague had apparently broken out. The crew of the ship were also to spend 15 days in quarantine and their goods were to be burnt, a common method of ridding items of infection. ${ }^{33}$ No further action was taken against plague, and by the time the disease next threatened Aberdeen six years later, the council had secured the services of James Cumming as the city's resident physician.
Although it is a necessarily speculative contention, it could be argued that Cumming's influence played a role in the authorities' decisive reaction to plague in 1506. Presumably responding to rumours of infection elsewhere, they put in place the usual measures to prevent it from entering the town: the official entrances were to be monitored, and inhabitants were ordered to strengthen their back walls and prohibited from lodging outsiders. ${ }^{34}$ Additionally, extra safeguards were imposed to establish the presence of infection at the earliest possible opportunity, with residents ordered to declare any sickness within their household and to remain housebound without receiving any visitors if they did fall sick. $^{35}$ It is important to note that none of these measures points to the actual presence of plague within the city boundaries. Rather, it shows the lengths to which the council was prepared to go to prevent infection from breaking out, even though such orders were both inconvenient and impractical. This is shown by the subsequent conviction of several residents for lodging outsiders and buying in wool from what the council identified as 'suspect folks and places' in spite of the threat of plague. ${ }^{36,37}$

While there was no mention of the council explicitly seeking advice from Cumming, it might plausibly be suggested that the physician's expertise was called upon the following year to tackle the renewed threat of the Great Pox. It was termed on this occasion the 'strange sickness of Naples', nomenclature used throughout the continent, which suggests that the Aberdeen authorities believed soldiers participating in Charles VIII's campaign to be responsible for initially spreading the disease. Magistrates ordered that all sufferers were to undergo 'diligent inquisition' and that those found to be infected were to stay within their own houses and yards, away from healthy residents, particularly butchers, bakers and brewers. $^{38}$ It is possible that, as a trained physician, Cumming would have carried out the examination of suspected Great Pox sufferers.

While Aberdeen had been remarkably fortunate to have avoided plague for so long this was not to last, and it is possible to speculate that the authorities' delay in responding to the threat of infection was at fault. Plague had broken out in Edinburgh in October 1512, but the council in Aberdeen took a whole year to implement some of its usual preventative measures, which were limited to forbidding strangers or travellers from being lodged within the city, ordering that animals were to be tethered and decreeing that communal water supplies were to be cleaned up (since polluted or stagnant water was a particular source of infection). ${ }^{39}$ No specific orders were declared for monitoring the town's entrances, however, and by April I 5 I 4 plague was 'ringing in all parts about this burgh'. ${ }^{40}$ Remarkably, this was the first definite occasion in history that plague had broken out within Aberdeen itself. 


\section{THE |5 |4-|6 PLAGUE EPIDEMIC}

In spite of the presence of plague within the city, the council responded by passing regulations that were mostly familiar and were designed to prevent further infection from entering the town from outside. No visitors 'coming forth of suspect places' were allowed to stay without a licence, and their hosts were to vouch that they were safe, in other words, free from infection. ${ }^{31} \mathrm{~A}$ local government official was to be told of any visitor's identity. The authorities were probably acting on past experience here, as convictions during the threatened outbreak of I 506 had taught them it was unrealistic to expect that no-one would be able to enter the town unnoticed by the watchers or that residents would not secretly lodge outsiders despite officials' best efforts. The council attempted to tackle this problem during the town's first plague outbreak by ordering that all common areas and passageways were to be secured, emphasising the necessity of ensuring security at these most vulnerable spots. ${ }^{42}$

Aside from the issue of security, it was also considered a priority to search houses regularly in order to identify residents who fell sick. Legislation was also passed against receiving goods and harbouring people from suspected places, while animals were ordered to be tethered and beggars were to be banished (not least because they were often visitors rather than being native to the town).

\section{NEW MEASURES TO TACKLE INFECTION}

Some significant developments also took place during the epidemic that showed how the authorities began to understand, perhaps due to Cumming's advice, the importance of cleansing goods and quarantining sufferers. They also demonstrated that they were able to cope with more urgent circumstances brought about by the presence of plague. It had previously been council policy that infected residents were enclosed in their houses, but in 1514 plague lodges were built outside the boundaries of the town, on the Links area by the beach. Residents who had already fallen victim to plague and those who were suspected of being infected were sent there until they either died or recovered.

Those fortunate enough to fall into the latter category were to remain in quarantine for a further 40 days, and cleanse their own clothes and goods to remove any infection. They would then be allowed to return to the town. Once back at home, they were to remain enclosed within their house for another 15 days before being allowed to attend communal gatherings such as church or market. Despite these stringent regulations there was still a risk that they could be infected, so they were forced, by a nationwide Act of Parliament, to carry a white stick for 20 days so that healthy residents could identify (and, if they so chose, avoid) them. ${ }^{43}$
The authorities also appointed an official cleanser, who oversaw the burning or boiling of infected goods to limit the risk of contagion. By October 1515 the council was forced to recognise that its cleanser, Androw Mortymer, was no longer able to cope on his own and granted him the services of a freeman, whom he was to choose himself. ${ }^{44}$ Besides the necessity of appointing an assistant to the cleanser, there are other indications that the town could not cope with the sheer numbers infected by plague. The following month, four people were banished from the town because they were found guilty of burying a poor man 'that died in the pestilence' in a midden in a close. ${ }^{45}$ This shows the insufficient provision there must have been for the burial of an increased number of dead. It also provides a clear indication of the unsanitary (although typical) conditions present in the town. It is perhaps a wonder that the council did not make more stringent efforts to clean up the streets, especially given its acknowledgement of the need to promote a clean environment.

Despite this, the epidemic finally ran its course and by the end of January 1517 the council was at last able to refer to the 'time of the last plague of pestilence'. ${ }^{46} \mathrm{After}$ the outbreak of 1514-16, Aberdeen was to experience remarkably few epidemics of plague. The city was hit by another major epidemic in 1545-47 and again in 1549 but thereafter, despite being encircled by plague on several occasions during the early seventeenth century, it was to be almost 100 years before plague broke out within the town boundaries again. When it did, in April 1647, it proved to be Aberdeen's final - and most virulent - epidemic. ${ }^{47}$

\section{DISCUSSION}

The Aberdeen authorities' efforts to prevent the spread of disease in the early sixteenth century were based on the belief that infection could be spread by both miasmas or by contagion. Initial government legislation was concerned with preventing plague from entering the burgh at all, and certainly this was achieved before 1514 . Most of the measures passed by the council were reimposed at the renewed threat of plague; the entrances to the town were to be closed or monitored, surrounding walls were to be strengthened, no visitors were to be lodged, animals were to be tethered, middens were to be removed from the streets and the water supplies were to be cleaned up.

When plague did eventually break out, in 1514 , the authorities built on these regulations and introduced new measures to identify and segregate sufferers, who were sent to purpose-built plague huts outside the town, and to combat the presence of infection by officially appointing cleansers to disinfect goods. By the end of Aberdeen's first plague outbreak a form of quarantine in stages was implemented with the gradual 
reintroduction into healthy society of those recovering from infection. Although no demographic statistics exist to enable us to quantify precisely how many residents of Aberdeen died from plague, it is evident that the epidemic affected everyone in the city, from the council member deciding how best to tackle the disease, to the trader whose goods had to be burnt, to the man punished for allowing his visiting friend to lodge with him. While the bacteriological identification of historical plagues is unlikely ever to be established with complete certainty, it should be noted that bubonic plague has a mortality rate of around $60 \%$ in untreated cases, while both the pneumonic and septicaemic strains of the disease have a mortality rate approaching $100 \%$ if untreated. ${ }^{48}$ The conjectured presence of either strain, or an earlier manifestation of them, would therefore most likely have caused significant numbers of deaths.

It is widely acknowledged that the Italian city states led the way in the devising and enacting of plague legislation. Quarantine measures, for example, which were first implemented in Scotland in the burgh of Peebles in 1468 , had been introduced in Milan in 1374; Milan also led the way in introducing plague huts, which were first used to house sufferers during the epidemic of 1449-52. ${ }^{49-53}$ Urban authorities in Scotland, and Aberdeen in particular, were remarkably far in advance of their English counterparts in promulgating legislation designed to tackle either plague or the Great Pox. To emphasise the speed with which the city's authorities responded to the Great Pox in particular, it is worth noting that during that same month a group of scholars gathered at the court of the Italian duke Ercole d'Este in Ferrara to discuss the new disease, a meeting which was 'the earliest major academic debate on mal francese'. ${ }^{54}$ Although the Great Pox may have been spread to England by mercenaries fighting under Warbeck in September 1496, it was not until 1502 that the disease was specifically acknowledged there (on which occasion it was termed the 'French pox'). ${ }^{48}$

\section{NOTES}

* Commentators also noted that the disease seemed to have declined in virulence only a few decades after its first appearance in Europe.

$\dagger \quad$ This extreme form of segregation implies a belief that the disease could be spread via the air as well as through sex. The term 'grandgor', though not employed by the Aberdeen authorities, was a term with French origins (grand gore meaning large sore).
It was a similar case with plague. In England plague legislation was first implemented only in 1518 , and then at the national rather than provincial level; it was not until the early seventeenth century that most major towns established their own legislation. As one leading scholar has remarked, "by comparison with Italy or France, it was in this respect a benighted, backward country. ${ }^{55}$ Not only did England lag behind Italy or France but also behind Scotland, where regulations to tackle the threat of plague had been implemented at least by I40I. That Aberdeen did not regularly implement its own local measures until 1498 - still a full 20 years before the first regulations were passed in England - might in part be attributable to the success of local measures elsewhere in Scotland during the fifteenth century to curb the spread of plague. One important conclusion to draw from this comparative chronological consideration of the implementation of plague legislation is that Scotland was by no means peripheral within Europe in intellectual, municipal and medical developments, just as Aberdeen was by no means peripheral within Scotland.

\section{CONCLUSION}

This discussion has highlighted the significance of the period 1495-1516 for medical developments in Aberdeen. The city's authorities became the first civic body in the British Isles to legislate against the Great Pox and, with the establishment at King's College of the first royally endowed Chair of Medicine at a British university, the city gained its first resident physician.These developments came only a few years before the city's first plague outbreak, during which the council implemented concerted measures against the transmission of disease through both miasma and contagion, measures which would be called upon in subsequent epidemics.
¥ The traditional identification of medieval and early modern accounts of 'plague' as being modern bubonic plague (whose bacterial agent, Yersenia pestis, was first discovered in 1894) has been questioned in recent years in light of a re-examination of contemporary evidence such as the apparent speed of transmission, the symptoms presented by sufferers, recorded mortality rates and the possible absence of Rattus rattus, whose fleas are largely, though not solely, responsible for the spread of bubonic plague. Recent scholarship has postulated that historical 'plagues' might rather be attributed to an airborne virus transmitted interpersonally, such as Ebola virus, or an earlier form of $Y$. pestis in combination with other strains such as pneumonic plague or secondary diseases such as influenza. 


\section{REFERENCES}

I Tognotti E. The rise and fall of syphilis in Renaissance Europe.J Med Humanit 2009; 30:99-II3. doi:10.1007/s 109/2-009-9079-3

2 Sefton AM. The Great Pox that was... syphilis. J Appl Microbiol 200I; 91:592-6. doi:10.1046/j.1365-2672.2001.01494.x

3 Aberdeen City Archives: Council Registers [hereafter ACR]. vol. 7. p. 767 [2I April 1497].

4 Morton RS. Some aspects of the early history of syphilis in Scotland. Brit J Vener Dis 1962; 38:175-80.

5 Arrizabalaga J, Henderson J, French R. The Great Pox: the French disease in Renaissance Europe. New Haven: Yale University Press; 1997. p. 36

6 Marwick JD, editor. Extracts from the records of the burgh of Edinburgh 1403-| 528. Edinburgh: Scottish Burgh Records Society; 1869. p. 7|-2 [22 September 1497].

7 Simpson JY. Antiquarian notices of syphilis in Scotland in the 15th and 16th centuries. Edinburgh: Edmonston \& Douglas; 1862. p. 14-5.

8 Contamine P. Scottish soldiers in France in the second half of the fifteenth century: mercenaries, immigrants or Frenchmen in the making? In: Simpson GG, editor. The Scottish soldier abroad, I2471967. Edinburgh: John Donald; 1992. p. 16-30.

9 MacDougall N. James IV. East Linton: Tuckwell; 1997. p. 128 p. II 4-5.

10 Pearce JM. A note on the origins of syphilis. J Neurol Neurosurg Psychiatry 1998; 64:542. doi:10.1 I36/jnnp.64.4.542

I I Dunlop D.The 'masked comedian': Perkin Warbeck's adventures in Scotland and England from 1495 to 1497. Scot Hist Rev 199I; 70:97-128.

12 Macfarlane LJ. William Elphinstone and the kingdom of Scotland, | 43 I-15 |4: the struggle for order. Aberdeen: Aberdeen University Press; 1985. p. 322-3.

13 Croft Dickinson W, editor. Early records of the burgh of Aberdeen, 13/7, 1398-1 407. Edinburgh: Scottish History Society; 1957. p. 2 II.

14 Leslie J. The historie of Scotland. Vol. I. Edinbugh: Scottish Text Society; I888. p. 47.

I5 Ell SR. Interhuman transmission of medieval plague. Bull Hist Med 1980; 54:497-510.

16 Twigg G. The Black Death: a biological reappraisal. London: Batsford; 1984.

17 Martin AL. Plague? Jesuit accounts of epidemic disease in the sixteenth century. Kirksville: Sixteenth Century Studies; 1996.

18 Cohn SK Jr. The Black Death transformed: disease and culture in early Renaissance Europe. London: Edward Arnold; 2002.

19 Carmichael A. Review essay: plagues and more plagues. Early Sci Med 2003; 8:253-66. doi:10.1163/157338203X00080

20 Scott S, Duncan C. Return of the Black Death: the world's greatest serial killer. Chichester: Wiley; 2005.

2I Theilmann JM, Cate F.A plague of plagues: the problem of plague diagnosis in medieval England. I Interdiscipl Hist 2007; 37:37I-93. doi:I0.II62/jinh.2007.37.3.37I

22 Watt DER. Biographical dictionary of Scottish graduates to A.D. I 10 . Oxford: Clarendon Press; 1997. p. 538-9.
23 Munro AM, editor. Register of burgesses of guild and trade of the burgh of Aberdeen, 1399-163I. In: The miscellany of the New Spalding Club.Vol. I. Aberdeen: New Spalding Club; 1890. p. 8, 12, 26, 28.

24 ACR.Vol. 8. p. 543 [30 January I506].

25 ACR.Vol. I3. p. 160 [22 May I53I].

26 ACR.Vol. 8. p. 278 [20 October I503].

27 Carmichael AG. Contagion theory and contagion practice in fifteenthcentury Milan. Renaissance Quart 1991; 44:213-56.

28 Kinzelbach A. Infection, contagion, and public health in late medieval and early modern German Imperial towns. J Hist Med Allied Sci 2006; 61:369-89. doi:10.1093/jhmas/jrj046

29 ACR.Vol. 7. p. 934-6 [19 May 1498]

30 ACR.Vol. 7. p. 957-8 [17 May 1499]

3I ACR.Vol. 7. p. 963 [2I June 1499].

32 ACR.Vol. 7. p. 993-4 [25 October 1499].

33 ACR.Vol. 7. p. 1067-8 [2I August 1500]

34 ACR.Vol. 8. p. 582 [8 June I506].

35 ACR.Vol. 8. p. 576 [25 May I506].

36 ACR. Vol. 8. p. 585 [20 June 1506]

37 ACR.Vol 8. p. 59 I [7 July I506].

38 ACR.Vol. 8. p. 753-4 [8 August I507].

39 ACR.Vol. 9. p. 268 [7 October I5I3].

40 ACR.Vol. 9. p. 336 [24 April 15I4]

41 ACR.Vol. 9. p. 338 [24 April I5/4].

42 ACR.Vol. 9. p. 339 [24 April I5I4].

43 ACR.Vol. 9. p. 367 [7 August 15।4].

44 ACR.Vol. 9. p. 509 [19 October I5I5]

45 ACR.Vol. 9. p. 518 [16 November 15I5]

46 ACR.Vol. 9. p. 66I [26 January I5I7].

47 jillings K. Preventing plague in post-Reformation Aberdeen. Int Rev Scot Stud 2005; 30:108-34.

48 Zhou D, Han Y, Yang R. Molecular and physiological insights into plague transmission, virulence and etiology. Microbes Infect 2006; 8:273-84. p. 274. doi:I0.10I6/j.micinf.2005.06.006

49 Carmichael AG. Plague legislation in the Italian Renaissance. Bull Hist Med 1983; 57:508-25.

50 Carmichael AG. Plague and the poor in Renaissance Florence. Cambridge: Cambridge University Press; 1986.

51 Cipolla C. Public health and the medical profession in the Renaissance. Cambridge: Cambridge University Press; 1976.

52 Palmer RJ. The control of plague in Venice and northern Italy, 13481600. PhD thesis, University of Kent at Canterbury; 1978.

53 Henderson J. Epidemics in Renaissance Florence: medical theory and government response. In: Bulst N, Delort R, editors. Maladie et société (XIle-XVIIle siècles). Paris: Editions du CNRS; 1989. p. $165-86$.

54 Eamon W. Plagues, healers, and patients in early modern Europe. Renaissance Quart 1999; 52:474-86. doi:10.2307/2902061

55 Slack P. The impact of plague in Tudor and Stuart England. Oxford: Oxford University Press; 1985. p. 200-I. 